\title{
Listen to these voices!
}

\begin{tabular}{|c|c|}
\hline \multicolumn{2}{|c|}{$\begin{array}{l}\text { Book Title: } \\
\text { Mother Earth, Mother Africa } \\
\text { \& Mission }\end{array}$} \\
\hline \multicolumn{2}{|l|}{ Book Cover: } \\
\hline \multicolumn{2}{|c|}{$\begin{array}{l}\text { MOTHER EARTH, } \\
\text { MOTHER AFRICA } \\
\text { \& } \\
\text { AFRICANINDIGNOUS RELIIIONS }\end{array}$} \\
\hline \multicolumn{2}{|c|}{$\begin{array}{l}\text { Author: } \\
\text { S. Daniel, M.D. Kabeneilwe \& } \\
\text { A. Savala (eds.) }\end{array}$} \\
\hline \multicolumn{2}{|c|}{$\begin{array}{l}\text { ISBN: } \\
\text { 978-1-991201-30-0 }\end{array}$} \\
\hline \multicolumn{2}{|c|}{$\begin{array}{l}\text { Publisher: } \\
\text { African Sun Media, 2021, } \\
\text { R275.00 } \\
\text { *Book price at time of review }\end{array}$} \\
\hline Review Title: & Listen to these voices! \\
\hline \multicolumn{2}{|c|}{ Reviewer: } \\
\hline \multicolumn{2}{|c|}{$\begin{array}{l}\text { Affiliation: } \\
{ }^{1} \text { Faculty of Theology, } \\
\text { North-West University, } \\
\text { Potchefstroom, South Africa }\end{array}$} \\
\hline \multicolumn{2}{|c|}{$\begin{array}{l}\text { Corresponding author: } \\
\text { Elizabeth Cornelius, } \\
\text { 10072152@nwu.ac.za }\end{array}$} \\
\hline \multicolumn{2}{|c|}{$\begin{array}{l}\text { How to cite this book review: } \\
\text { Cornelius, E.M., 2021, 'Listen } \\
\text { to these voices!', In } \\
\text { die Skriflig 55(1), a2793. } \\
\text { https://doi.org/10.4102/ids. } \\
\text { v55i1.2793 }\end{array}$} \\
\hline \multicolumn{2}{|c|}{$\begin{array}{l}\text { Copyright: } \\
\text { (C) 2021. The Authors. } \\
\text { Licensee: AOSIS. This work } \\
\text { is licensed under the } \\
\text { Creative Commons } \\
\text { Attribution License. }\end{array}$} \\
\hline \multicolumn{2}{|l|}{ Read online: } \\
\hline 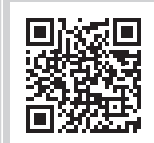 & $\begin{array}{l}\text { Scan this QR } \\
\text { code with your } \\
\text { smart phone or } \\
\text { mobile device } \\
\text { to read online. }\end{array}$ \\
\hline
\end{tabular}

This book was published after the 5th Pan African Circle of Concerned African Women Theologians Conference in Botswana in July 2019. The title of this book is related to the theme of the conference: 'Mother Earth and Mother Africa in Theological, Religious, Cultural, and Philosophical Imagination'. Mother Earth, Mother Africa E Mission saw the light in 2021 while Mother Earth suffers due to not only climate changes and global warming, but also the COVID-19 pandemic. Africa forms part of the global Earth community, which is also experiencing the current ecological crisis that includes the silencing of women. The question addressed is the following: What is humankind's mission or duty towards Mother Africa on Mother Earth? The assumption that imbalanced relationships also affect the well-being of Mother Earth, necessitated the authors to navigate a three-way intersection between ecology, mission and gender. The chapters in this book cover various topics, which address perspectives that need to be re-imagined in order to contribute to the quest for an eco-gendered just world. Eleven authors, within the fields of theology, history and sociology contributed nine chapters in three parts: re-imagining theological perspectives on women and the earth, re-imagining women's oppression and the earth, and re-imagining women as change-agents who care for the earth.

In part 1 , one finds a re-imagination of the mission of the Pentecostal churches, of salvation and of the mission of the church. Authors Kebaneilwe and Scotch state in Chapter 1 that, in the past, the church was focused on resignation from the world in order to be kept holy. Current Pentecostal churches, however, became more worldly involved and the context of the reader became important. However, there is a lack of concern about environmental issues. The authors voice the need to re-imagine the Pentecostal mission to develop responses to the environmental crisis. In Chapter 2, Mulambya-Kabonde re-imagines 'salvation' as not only relevant for all humankind but for all 'creation'. Creation needs salvation and healing because of social, political, economic, spiritual and ecological disasters. One of these disasters is the crippling of women through patriarchy which needs to be addressed. The author claims that salvation encompasses the rich and poor, the strong and weak, female and male, and embraces humanity and teaches humanity to embrace God's creation. In Chapter 3, the mission of the church is re-imagined to be the protection of the earth. This article is presented in French, which can limit access to the insights of the author, Gandonou.

In part 2, one reads about re-imagining women's oppression. In Chapter 4, Mombo explains that as part of missionary work in Africa, women got the opportunities to work in veggie gardens in order to provide for their households. This happening was significant in affirming the role of women in the production of food.

However, it also played a role in creating womanhood and it became an oppressive and hierarchical system through which women remained in the domestic sphere, while men could grow in the public sphere. In Chapter 5, the focus is on women's disempowered status on land ownership. Matlhaope is of the opinion that land is an economic resource, and that denying women its ownership, is a serious setback to inclusive socio-economic development. Savala writes in Chapter 6 about the situation in Kenya where women are the ones taking care of the gardens, providing for families, cleaning water, collecting wood - and Savala believes that these women should be empowered by redefining headship. Savala's theorising on female headship calls for the allowance of women to exercise their God-given endowment of grace to work in the environment and take care of it.

In part 3, women are re-imagined as change agents who can care for the earth. In Chapter 7, the focus is on Cameroon, and Tabe refers to a story in African women's storytelling about priestesses in Cameroon - spiritual leaders who preserved nature. These priestesses have, however, been stigmatised and demonised by male Christian missionaries who called them witches. In this way, they disappeared from the scene and the author wants to advocate a return to traditional spirituality and habits of nature conservation. The author believes that Ejagham would have been a better entity, had these women been allowed to thrive with their religio-spiritual association. 
In Chapter 8, Mwale advocates the celebration and recognition of Zambian scholarship of women who made a difference in promoting the care of the earth. In Zambia, at the Kasisi Agricultural Training centre, many women contributed towards sustainable agriculture and Mwale presents the narratives of two women who received training at this centre. This chapter voices these women's stories. Chapter 9 concludes this book with Bolaane and Lesetedi's description of the roles women play in Botswana in the fire-churches in leadership roles and in the ministry.

Various scriptural passages are interpreted throughout the book from both the Old and New Testament. Genesis 1:26-28 plays an important role to argue that both males and females were included by God in headship over the creation. The roles of headship are discussed from Ephesians 5:21-33 as servanthood, love and protection. Matthew 15:19-20 is interpreted to prove that sin separates humankind from God. The whole creation's groaning in Romans 8:19-25 is interpreted as creation's yearning to be liberated from bondage. Philippians 1:6, Matthew 4:34-38 and Luke 10:30-37 are also interpreted in this regard. It is shown from John 1:1-3 and 9-10 that the enfleshment of the Logos is God's way of dwelling in the world, meaning that God not only created the world, but also descended and showed that the
Divine is inseparable from the worldly realm. Matthew 3:1617 is used to argue that, Jesus being baptised in water, shows a close relationship between him and nature. Jesus' response to Satan in Matthew 4:3-4 is interpreted to show that he is advocating for the sustainable use of environmental resources. In Chapter 3 (in French), various Old and New Testament passages are referred to.

The approaches followed in this book vary from the ethnographic approach (Chapter 9), socio-economic and political development approaches, to socio-rhetoric and synchronic methodologies (Chapter 5), to inculturation hermeneutics (Chapter 1), to a gendered analytical and contextualised study (Chapter 2), to a storytelling methodology (Chapter 7). It seems as if the overall aim of this book is to appropriate and contextualise Scripture in order to address current concerns.

This book is believed to contribute to theological discussions on the ecological crisis, the subjugated role of women, and the preservation of Mother Earth. It brings together the voices of women in Africa, it attempts to step into academic discourses on ecofeminism, and it introduces the reader to new research on women in Africa. The outcome of my review is to encourage scholars to listen to these voices! 